\title{
Assessment of Groundwater Potential Zones across Katrol Hill Fault, Kachchh, Western India: A Remote Sensing and GIS Approach
}

\author{
Hemashri Thacker'1, Yash Shah', Akshay Jyoti Borah'1, Yogendrasinh Jadeja², \\ Mahesh Thakkar ${ }^{1}$, Sazina Bhimani ${ }^{3}$, Gaurav Chauhan ${ }^{1}$ \\ ${ }^{1}$ Department of Earth and Environmental Science, KSKV Kachchh University, Bhuj, India \\ ${ }^{2}$ Arid Communities and Technologies (ACT), Bhuj, India \\ ${ }^{3}$ Geo Science Services (GSS), Bhuj, India \\ Email: *mgthakkar@rediffmail.com
}

How to cite this paper: Thacker, H., Shah, Y., Borah, A.J., Jadeja, Y., Thakkar, M., Bhimani, S. and Chauhan, G. (2022) Assessment of Groundwater Potential Zones across Katrol Hill Fault, Kachchh, Western India: A Remote Sensing and GIS Approach. Open Journal of Geology, 12, 111-135. https://doi.org/10.4236/ojg.2022.122006

Received: December 30, 2021

Accepted: February 18, 2022

Published: February 21, 2022

Copyright $\odot 2022$ by author(s) and Scientific Research Publishing Inc. This work is licensed under the Creative Commons Attribution-NonCommercial International License (CC BY-NC 4.0). http://creativecommons.org/licenses/by-nc/4.0/ (c) (i) (3) Open Access

\begin{abstract}
The present study focuses on the use of remote sensing and geographical information system tools for morphometric and geomorphic analysis of major river basins across the Katrol Hill Fault, which makes drainage divide. It aims to find groundwater potential for the management and planning of groundwater resources. The study area consists of 6 major watersheds of major river systems namely Bhurud, Khari, and Pat flowing north of the major divide, while Rukmawati, Nagavanti, and Bhukhi are southerly flowing rivers. Based on linear, areal, and geomorphic aspects, a watershed with excellent groundwater potential was found. The highest order in the area is the 5th order stream. Appropriate drainage network characteristics, elongated shape, and permeable lithological formation with low relief among all the watersheds made WS3 be excellent potential for groundwater. The statistical analysis, where $\mathrm{Cp}$ value was computed, showed the potential groundwater zone to be in WS3 followed by WS2 and WS5. These results were even verified with field data, collected from well-inventory and that too favored WS3 as an excellent groundwater potential.
\end{abstract}

\section{Keywords}

Katrol Hill Fault, Kachchh, Groundwater Potential, Statistical Analysis, Groundwater Resources

\section{Introduction}

Kachchh falls under the arid to the semi-arid climatic region of the Indian 
sub-continent and also comes under the most sensitive "Zone-V" of the seismic zonation of India [1]. People here are mostly dependent on groundwater sources for domestic, agriculture, industrial, and irrigation purposes. Overexploitation of the groundwater and increasing discharge from the deeper sources without considering the lithology resulted in the depletion of the water table and quality. Hence, the saline sources deteriorate the fresh groundwater reservoirs. The major E-W trending faults and numerous transverse faults with the dykes and joints present in the basin play a significant role in the quality, quantity, and recharge potential of the groundwater.

The morphometric study happens to be a prime tool to understand the attributes of groundwater conservation and management. To determine the shape and dimension of the landform, the configuration of the basin surface is mathematically analyzed [2]. In earlier studies, conventional methods have been used to study surface drainage pattern characteristics, which have some constraints in terms of a large drainage network over a whole river basin. To overcome it Remote Sensing data and GIS prove a very effective method for studying the drainage pattern, drainage density, linear, aerial, and relief aspects of the basin by providing aerial photographs and satellite images [3] [4] [5] [6].

Many researchers have worked earlier with this method for example morphometric research was conducted of the Bharathapuzha River watershed, using geoprocessing techniques in GIS, in which they studied stream order, slope, drainage density, elongation ratio, and other parameters. Their results showed that for basin management and other hydrological studies combination of remote sensing data and geoprocessing units shows an effective tool [7]. In one of the studies on the Pageru River basin by [8], the drainage characteristics and other morphometric parameters are determined. Their results revealed that on evaluation of Drainage density, subsurface strata are permeable; the mean $\mathrm{Rb}$ shows no sway of geological structures on drainage pattern, the quantitative analysis reveals complex morphometric attributes the dominance of lower-order streams in the basin with stream segments affected majorly by rainfall and thrusting \& faulting being responsible for the elongated shape of the basin [8]. With these, various features of morphometric aspect have had some links being understood by them, which will assist in locating sites for artificial recharge structures. Morphometric analysis has been carried out by many researchers in the Kachchh region in terms of the Morphostructural approach by [9], Quaternary landform development by [10], Implication on Neo-tectonics by [11], in hydrogeology for the formulation of management methods for coastal aquifers of Mundra region, Kachchh, by [12], etc. But the present study is focused on morphometric and geomorphic analysis using remote sensing data and GIS tools in terms of hydrogeology, across a major drainage divide, to identify watersheds with good groundwater potential.

\section{Study Area}

The Kachchh region is the westernmost part of India, lying between latitudes 
$22^{\circ} 44^{\prime} 11^{\prime \prime}$ and $24^{\circ} 41^{\prime} 25^{\prime \prime}$ and between longitudes $68^{\circ} 09^{\prime} 46^{\prime \prime}$ and $71^{\circ} 54^{\prime} 47^{\prime \prime}$, as shown in Figure 1. It's the largest district of the Indian sub-continent with an area of 45,674 sq. $\mathrm{km}$. It is surrounded by the Great Rann of Kachchh in the north, Little Rann of Kachchh in the east, Gulf of Kachchh to the south, Arabian Sea from the SW-West, and Pakistan in the NW. It has hilly terrains, coastline, mud-flats, islands, Ranns, plains, and gulf (Figure 1).

Geologically, Kachchh has Mesozoic and Cenozoic strata deposited in a peri-cratonic rift basin formed in pre-Jurassic time, while the basin is not under the rest but still tectonically an active one. The present study area across the Katrol Hill Fault (KHF) occupies $1103.88 \mathrm{sq} \cdot \mathrm{km}$ area of the Kachchh mainland. The area covers the outcrops of Jumara, Jhuran, Bhuj, and Deccan traps rocks [1]. Kachchh mainland is divided from the center by KHF, which brings older formations in front of the younger formations resulting in drastic lithological changes. It covers six drainage basins, three north of the KHF and three are to the south, hence the KHF works as drainage divide from where six rivers originate. Bhurud, Khari, and Pat rivers flow to the north and meet to the plain of Banni crossing the Kachchh mainland fault (KMF) while Rukmawati, Nagavanti, and Bhukhi flow southerly cutting Deccan Traps, Tertiary, and Quaternary to meet the Gulf of Kachchh. Also, north-flowing rivers are flowing on the footwall of reverse KHF, which has more slope than south-flowing rivers flowing on hanging wall of reverse KHF which has a comparatively gentle slope. Because of sudden elevation drop, north-flowing rivers form delta when debouching in the

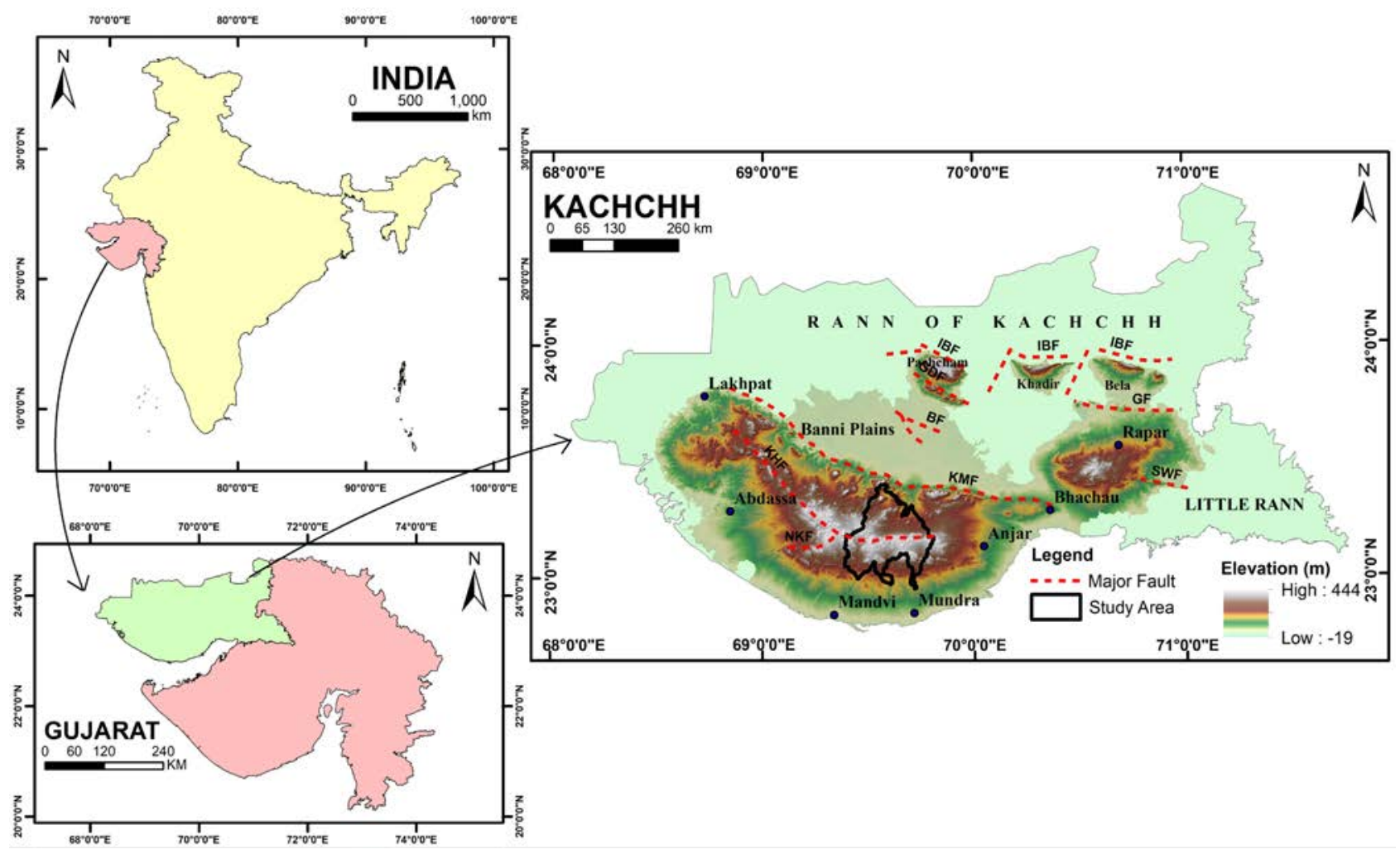

Figure 1. Location map of the study area along the Katrol Hill Fault (KHF). 
Banni Plains, while south-flowing rivers are forming fanning when pouring their water into the Arabian Sea. But on seeing the drainage map, we can see that rivers or streams are following linear paths perpendicular to the strikes of the strata for a longer distance, which suggests that these streams and the drainage network are controlled by the geological structures.

Due to the scanty rainfall with total rainy days being less than a week, the rivers happen to be ephemeral ones and often create flash floods during the rains. Hence the recharge of aquifers is mostly achieved by the precipitation and surface run-off water. Due to the scarcity of surface water resources groundwater becomes a major source for inhabitants [13]. Overdraft is the result of the increase in water demand due to uncertain spatial and temporal variations of rainfall [14].

\section{Data Used}

1) Advanced Land Observation Satellite-Phased Array Type L-band Synthetic Aperture Radar (ALOS PALSAR) data, with $12.5 \mathrm{~m}$ spatial resolution are acquired from the Alaska Satellite Facility website (https://asf.alaska.edu/) for the generation of drainage; as shown in Figure 2;

2) Sentinel-2 data (bands 8, 4 and 3), with $10 \mathrm{~m}$ spatial resolution is downloaded from USGS Earth Explorer (https://earthexplorer.usgs.gov/) to prepare the Geomorphology map and also for the verification of the drainage generated from ALOS data;

3) Toposheets at a scale of 1:50,000 are used to delineate the study area boundary and outline the natural drainage for DEM manipulation.

To verify the results, a field survey was carried out.

\section{Methodology}

Flowchart for methodology is shown in Figure 3.

In the study, the drainages and drainage-related parameters were generated from ALOS-PALSAR DEM (Advanced Land Observation Satellite-Phased Array Type L-band Synthetic Aperture Radar Digital Elevation Model) with the help of Arc Hydro Package toolset version 10.8. Arc Hydro tool requires a workflow process for the generation of the drainages. The watershed boundaries were delineated by defining pour points in the drainage network. The natural drainages are then outlined with the help of SOI Toposheet $(1: 50,000)$. The SOI Topo-sheets are geo-referenced in a GIS environment and the natural drainages are digitized manually. The drainage and watershed maps are given in Figure 4 and Figure 5 respectively.

Total numbers of six watersheds were identified in the area viz. WS-1 to WS-6 which are formed by the rivers namely, Bhurud, Khari, Pat, Rukmawati, Nagavanti, and Bhukhi. The area of these watersheds is calculated from the geometry of the derived watershed polygon. The length is calculated by totalizing the stretch of the primary channel \& the distance from the apex of the mainstream 


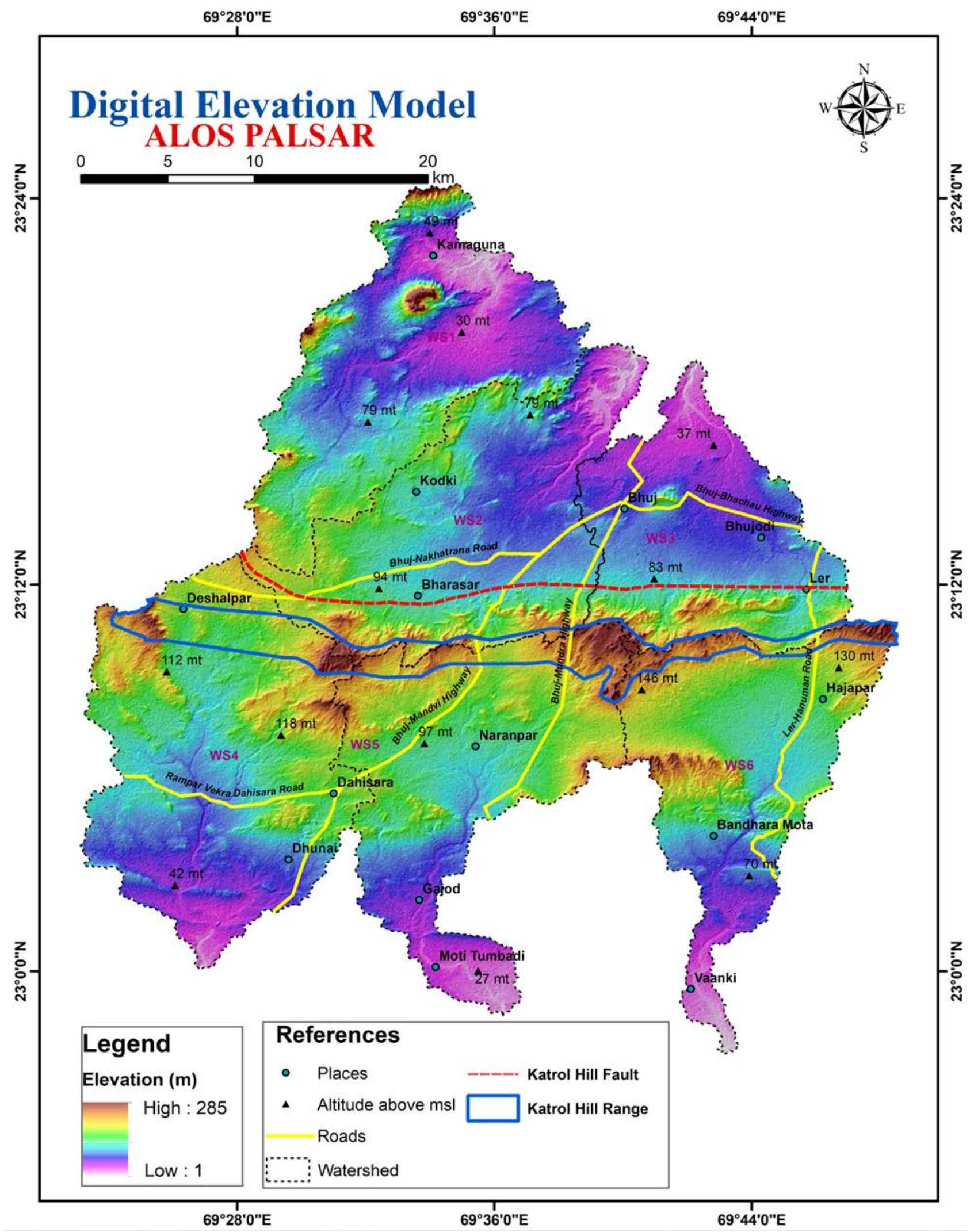

Figure 2. Digital Elevation Model (DEM) of the study area showing the Katrol Hill range and Katrol Hill Fault trending E-W. 


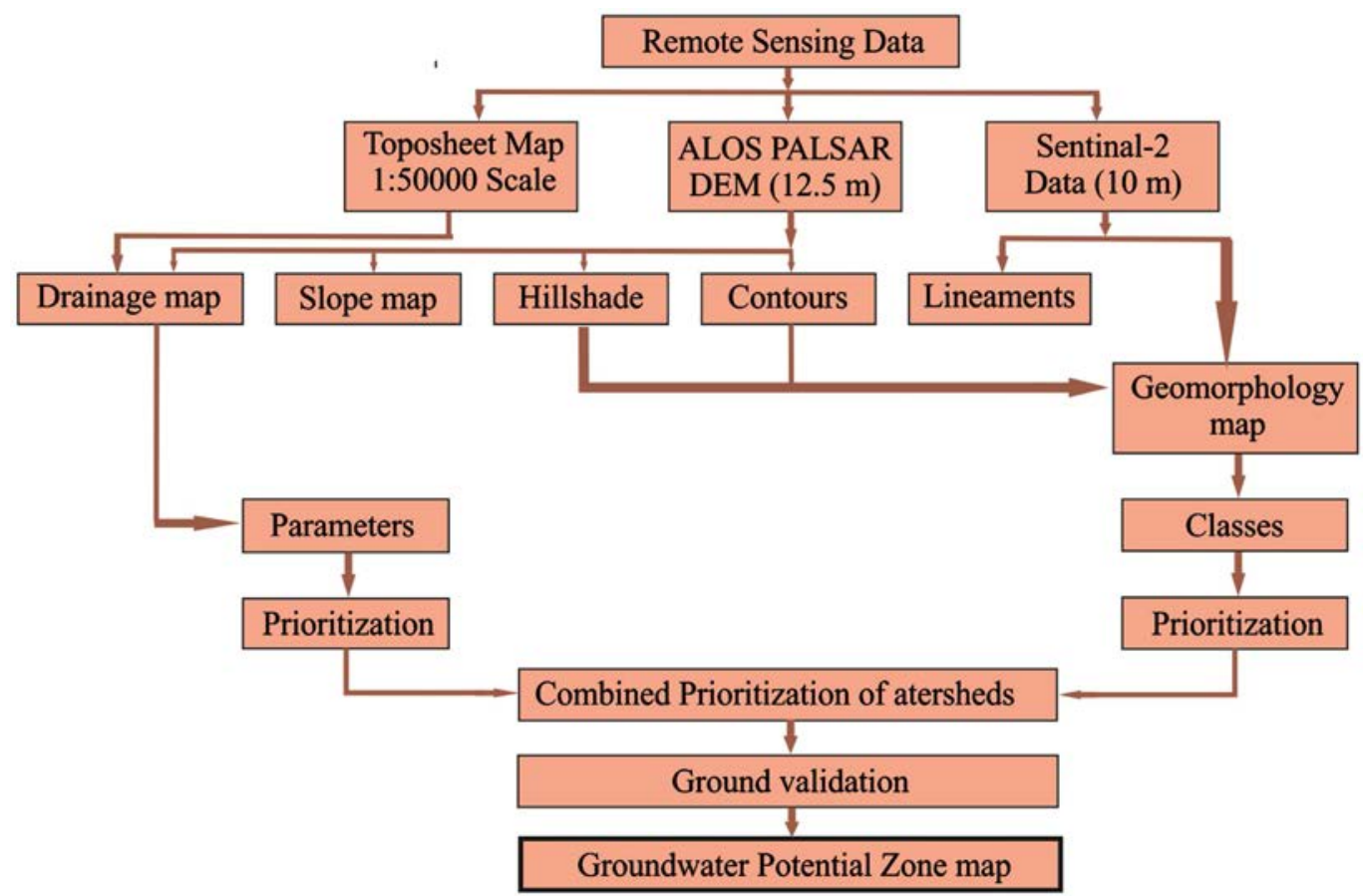

Figure 3. Flowchart for identification of groundwater potential zones using RS and GIS technique.

to the watershed boundary [15] [16]. The stream order was done by using [17] scheme for ordering. The mathematical formulae used for the derivation of the morphometric parameters are shown in Table 1. The morphometric parameters of all sub-watersheds are shown in Tables 2-4.

For the preparation of geomorphological maps multispectral Sentinel -2 data of $12.5 \mathrm{~m}$ spatial resolution was used. The classification was done manually by the visual image interpretation technique. A hill shade and a contour layer were also generated from the ALOS PALSAR DEM which was used as a reference in the preparation of the geomorphological map. The map was prepared by manual digitization of the features of satellite image and geomorphic features were identified.

The prioritization of the watersheds is done based on the degree of groundwater potential derived from morphometric parameters and geomorphic features. The six watersheds were ranked from rank 1 to 6 , in which rank 1 represents the lowest groundwater potential and the last represents the highest one. The average rank of all parameters of a particular watershed was designated as Compound value and was calculated by using the following equation:

$$
C_{p}=\frac{1}{n} \sum_{i=1}^{n} R_{i}
$$

where, $C_{p}$ is the Compound value of a particular watershed, $R_{i}$ is the Rank of a particular watershed for a parameter, $n$ is the number of parameters.

\section{Results and Discussion}

Kachchh is known for its prolonged aridity and continued tectonism. To understand structural controls over the landscape and the hydrological and morphological 


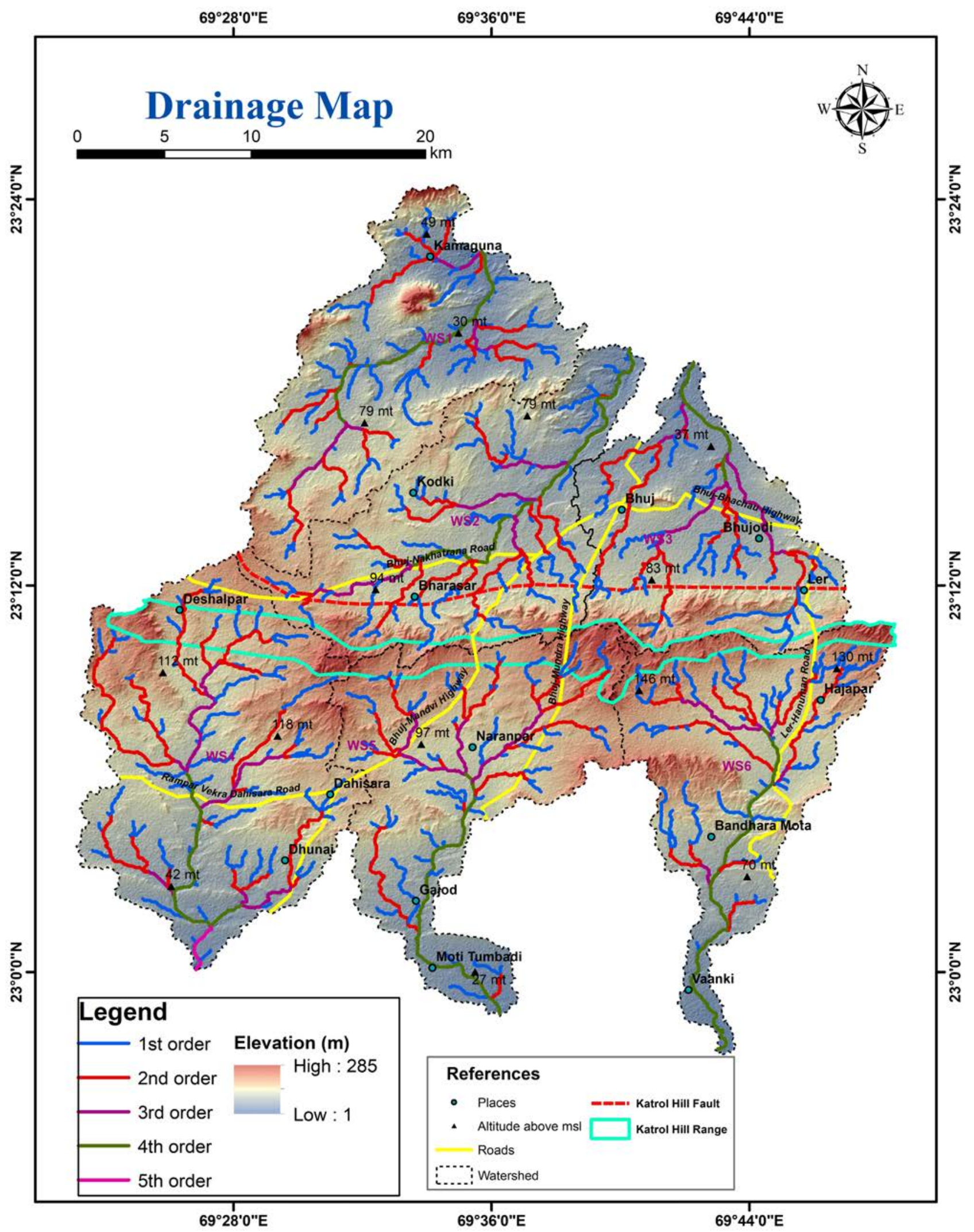

Figure 4. Drainage map of the study area. 


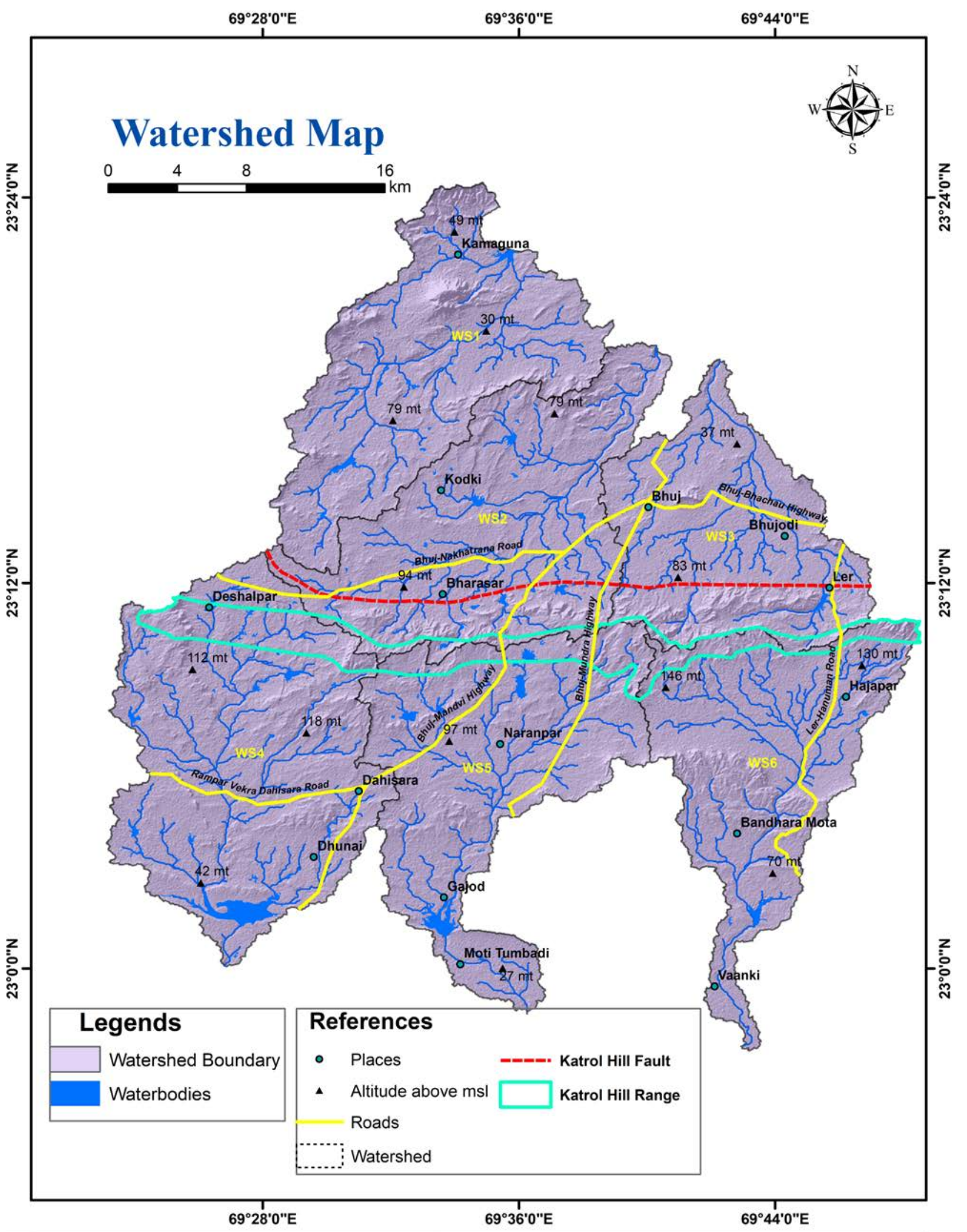

Figure 5. Watershed map showing three to the south and three to the north of the Katrol Hill Fault (KHF). 
Table 1. Formulae adopted for computation of morphometric parameters.

\begin{tabular}{|c|c|c|c|}
\hline Sl. No. & Morphometric Parameters & Formulae & Reference \\
\hline & Linear Parameters & & \\
\hline 1. & Stream Order & Hierarchical Rank & {$[18]$} \\
\hline 2. & Stream Length $(\mathrm{Lu})$ & Length of the stream & {$[3]$} \\
\hline 3. & Bifurcation Ratio $(\mathrm{Rb})$ & $\begin{array}{l}\mathrm{Rb}=\mathrm{Nu} / \mathrm{Nu}+1 \\
\text { where, } \mathrm{Rb}=\text { Bifurcation Ratio; } \\
\mathrm{Nu}=\text { Total no. of stream segments of order " } \mathrm{u} \text { "; } \\
\mathrm{Nu}+1=\text { Number of segments of the next higher order }\end{array}$ & [19] \\
\hline 4. & $\begin{array}{l}\text { Mean Bifurcation Ratio (Rbm) } \\
\text { Areal Parameters }\end{array}$ & $\mathrm{Rbm}=$ Average of bifurcation ratios of all orders & {$[20]$} \\
\hline 5. & Drainage Density (Dd) & $\begin{array}{l}\mathrm{Dd}=\mathrm{Lu} / \mathrm{A} \\
\text { Where, } \mathrm{Dd}=\text { Drainage density; } \\
\mathrm{Lu}=\text { Total stream length of all orders } \mathrm{A}=\text { Area of the basin }\left(\mathrm{km}^{2}\right)\end{array}$ & {$[21]$} \\
\hline 6. & Stream Frequency (Fs) & $\begin{array}{l}\mathrm{Fs}=\mathrm{Nu} / \mathrm{A} \\
\text { Where, } \mathrm{Fs}=\text { Stream frequency, } \\
\mathrm{Nu}=\text { Total no. of streams of all orders } \mathrm{A}=\text { Area of the basin }\left(\mathrm{km}^{2}\right)\end{array}$ & {$[21]$} \\
\hline 7. & Texture Ratio (Rt) & $\begin{array}{l}\mathrm{Rt}=\mathrm{N} 1 / \mathrm{P} \\
\text { where, } \mathrm{N} 1=\text { Total no. of streams of } 1^{\text {st }} \text { order; } \mathrm{P}=\text { Perimeter }\end{array}$ & {$[19]$} \\
\hline 8. & Form Factor (Rf) & $\begin{array}{l}\mathrm{Rf}=\mathrm{A} / \mathrm{Lb}^{2} \\
\text { where, } \mathrm{Rf}=\text { Form factor; } \mathrm{A}=\text { Area of the basin }\left(\mathrm{km}^{2}\right) \\
\mathrm{Lb}^{2}=\text { Square of basin length }\end{array}$ & {$[21]$} \\
\hline 9. & Circularity Ratio (Rc) & $\begin{array}{l}\mathrm{Rc}=4^{\star} \pi^{\star} \mathrm{A} / \mathrm{P} 2 \\
\text { where, } \mathrm{Rc}=\text { Circularity ratio; } \pi=\text { "Pi" value i.e. } 3.14 ; \mathrm{A}=\text { Area of } \\
\text { the basin }\left(\mathrm{km}^{2}\right) ; \\
\mathrm{P}=\text { Perimeter }(\mathrm{km})\end{array}$ & {$[22]$} \\
\hline 10. & Elongation Ratio (Re) & $\begin{array}{l}\mathrm{Re}=2 / \mathrm{Lb} \sqrt{ }(\mathrm{A} / \pi) \\
\text { where, } \mathrm{Re}=\text { Elongation ratio } \mathrm{A}=\text { Area of the basin }\left(\mathrm{km}^{2}\right) ; \\
\pi=\text { "Pi" value i.e. } 3.14 \\
\mathrm{Lb}=\text { Basin length }\end{array}$ & [19] \\
\hline 11. & Length of overland flow (Lg) & $\begin{array}{l}\mathrm{Lg}=1 / \mathrm{D}{ }^{\star} 2 \\
\text { where, } \mathrm{Lg}=\text { Length of overland flow; } \mathrm{D}=\text { Drainage density }\end{array}$ & [3] \\
\hline 12. & Shape index (Sw) & $\begin{array}{l}\text { Lb2/A } \\
\text { where, } L b=\text { Basin length; } A=\text { Area of basin }\end{array}$ & [3] \\
\hline 13. & Compactness coefficient (Cc) & $\begin{array}{l}\mathrm{Cc}=\mathrm{Pc} / \mathrm{Pu} \\
\text { where, } \mathrm{Pc}=\text { Perimeter of watershed; } \\
\mathrm{Pu}=\text { Perimeter of circle of watershed area }\end{array}$ & {$[23]$} \\
\hline Relief $F$ & arameters & & \\
\hline 14. & Basin relief $(\mathrm{H})$ & $\mathrm{H}=$ Maximum relief - Minimum relief & \\
\hline 15. & Relief ratio (Rhl) & $\begin{array}{l}\mathrm{Rhl}=\mathrm{H} / \mathrm{Lb} \\
\text { where, } \mathrm{H}=\text { Total relief } \mathrm{Lb}=\text { Basin Length }\end{array}$ & {$[19]$} \\
\hline
\end{tabular}


Table 2. Basin network characteristics of the watersheds.

\begin{tabular}{ccccccccc}
\hline Watershed & $\begin{array}{c}\text { Basin area } \\
\left(\mathbf{k m}^{2}\right)\end{array}$ & $\begin{array}{c}\text { Maximum } \\
\text { elevation } \\
(\mathbf{k m})\end{array}$ & $\begin{array}{c}\text { Minimum } \\
\text { elevation } \\
(\mathbf{k m})\end{array}$ & $\begin{array}{c}\text { Perimeter } \\
(\mathbf{k m})\end{array}$ & $\begin{array}{c}\text { Basin length } \\
(\mathbf{k m})\end{array}$ & $\begin{array}{c}\text { Perimeter of } \\
\text { circle of } \\
\text { watershed }(\mathbf{k m})\end{array}$ & $\begin{array}{c}\text { Total } \\
\text { number of } \\
\text { stream }\end{array}$ & $\begin{array}{c}\text { Total } \\
\text { stream }\end{array}$ \\
\hline lenth $(\mathbf{k m})$
\end{tabular}

Table 3. Stream characteristics of the watersheds.

\begin{tabular}{|c|c|c|c|c|c|c|c|c|c|c|c|c|}
\hline \multirow{2}{*}{$\begin{array}{l}\text { Watershed } \\
\text { Code }\end{array}$} & \multicolumn{6}{|c|}{ Stream number in different orders } & \multicolumn{6}{|c|}{ Order wise Total stream lengths (m) } \\
\hline & 1 & 2 & 3 & 4 & 5 & Total & 1 & 2 & 3 & 4 & 5 & Total \\
\hline WS1 & 65 & 30 & 14 & 20 & & 129 & 69.8 & 42.5 & 12.6 & 16.09 & & 140.99 \\
\hline WS2 & 65 & 29 & 14 & 21 & & 129 & 83.17 & 48.09 & 18.79 & 22.54 & & 172.59 \\
\hline WS3 & 45 & 29 & 11 & 4 & & 89 & 56.82 & 44.52 & 18.51 & 8.61 & & 128.46 \\
\hline WS4 & 74 & 38 & 19 & 13 & 3 & 147 & 91.44 & 65.94 & 22.77 & 13.69 & 3.15 & 196.99 \\
\hline WS5 & 60 & 32 & 13 & 14 & & 119 & 69.01 & 45.95 & 17.16 & 19.15 & & 151.27 \\
\hline WS6 & 53 & 30 & 9 & 13 & & 105 & 71.27 & 39.42 & 10.38 & 23.52 & & 144.59 \\
\hline
\end{tabular}

Table 4. Calculation of mean bifurcation ratio and stream length ratio.

\begin{tabular}{|c|c|c|c|c|c|c|c|c|c|}
\hline \multirow{2}{*}{$\begin{array}{l}\text { Watershed } \\
\text { Code }\end{array}$} & \multicolumn{5}{|c|}{ Bifurcation Ratio } & \multicolumn{4}{|c|}{ Stream Length ratio } \\
\hline & $1 / 2$ & $2 / 3$ & $3 / 4$ & $4 / 5$ & Mean Bifurcation ratio & $2 / 1$ & $3 / 2$ & $4 / 3$ & $5 / 4$ \\
\hline WS1 & 2.17 & 2.14 & 0.70 & & 1.67 & 0.65 & 0.42 & 1.15 & \\
\hline WS2 & 2.24 & 2.07 & 0.67 & & 1.66 & 0.74 & 0.65 & 1.61 & \\
\hline WS3 & 1.55 & 2.64 & 2.75 & & 2.31 & 0.99 & 0.64 & 0.78 & \\
\hline WS4 & 1.95 & 2.00 & 1.46 & 4.33 & 2.44 & 0.89 & 0.60 & 0.72 & 0.24 \\
\hline WS5 & 1.88 & 2.46 & 0.93 & & 1.76 & 0.77 & 0.54 & 1.47 & \\
\hline WS6 & 1.77 & 3.33 & 0.69 & & 1.93 & 0.74 & 0.35 & 2.61 & \\
\hline
\end{tabular}

attributes the drainage morphometric parameters are of great use [24] [25] [26] [27]. Apart from exogenic and endogenic forces, geology and rainfall of the area are the main governing factors for the development of drainage networks [28]. The present study was aimed to prioritize watersheds across the Katrol Hill Fault (KHF) for groundwater potentials by studying geomorphology and calculating various morphometric parameters with RS and GIS techniques. The morphometric parameters are discussed below. The ranks assigned to various watersheds based on morphometric parameters are described in Table 5. 
Table 5. Morphometry based watershed prioritization for groundwater potential.

\begin{tabular}{|c|c|c|c|c|c|c|c|c|c|c|c|c|c|}
\hline \multirow{2}{*}{ Watershed } & \multicolumn{12}{|c|}{ Morphometry } & \multirow{2}{*}{$\mathrm{Cp}$ Value } \\
\hline & $\mathrm{Dd}$ & Fs & $\mathrm{Rbm}$ & Rt & $\mathrm{Lg}$ & $\mathrm{Rc}$ & $\operatorname{Re}$ & $R f$ & $\mathrm{Cc}$ & Sw & $\mathrm{H}$ & Rhl & \\
\hline WS-1 & 0.79 & 0.72 & 1.67 & 0.71 & 0.63 & 0.27 & 0.74 & 0.43 & 1.92 & 2.31 & 0.284 & 0.139 & \\
\hline Rank & 6 & 1 & 5 & 2 & 6 & 3 & 4 & 4 & 3 & 4 & 1 & 2 & 3.42 \\
\hline WS-2 & 0.90 & 0.66 & 1.66 & 0.69 & 0.55 & 0.28 & 0.68 & 0.37 & 1.89 & 2.72 & 0.231 & 0.01 & \\
\hline Rank & 1 & 2 & 6 & 3 & 1 & 4 & 2 & 2 & 5 & 3 & 5 & 6 & 3.33 \\
\hline WS-3 & 0.89 & 0.61 & 2.31 & 0.64 & 0.56 & 0.36 & 0.91 & 0.65 & 1.66 & 1.54 & 0.223 & 0.0149 & \\
\hline Rank & 3 & 6 & 2 & 4 & 3 & 5 & 6 & 6 & 1 & 2 & 6 & 1 & 3.75 \\
\hline WS-4 & 0.83 & 0.62 & 2.44 & 0.82 & 0.60 & 0.37 & 0.78 & 0.47 & 1.65 & 2.11 & 0.238 & 0.0106 & \\
\hline Rank & 4 & 5 & 1 & 1 & 4 & 6 & 5 & 5 & 2 & 1 & 4 & 5 & 3.58 \\
\hline WS-5 & 0.82 & 0.64 & 1.76 & 0.59 & 0.61 & 0.23 & 0.71 & 0.39 & 2.09 & 2.53 & 0.256 & 0.0118 & \\
\hline Rank & 5 & 4 & 4 & 5 & 5 & 1 & 3 & 3 & 4 & 6 & 3 & 4 & 3.92 \\
\hline WS-6 & 0.90 & 0.65 & 1.93 & 0.57 & 0.56 & 0.24 & 0.64 & 0.32 & 2.05 & 3.09 & 0.284 & 0.0127 & \\
\hline Rank & 2 & 3 & 3 & 6 & 2 & 2 & 1 & 1 & 6 & 5 & 1 & 3 & 2.92 \\
\hline
\end{tabular}

\section{Linear aspects}

To get linear morphometric parameters, classification of streams into different orders $(\mathrm{u})$ [18], the number of streams $(\mathrm{Nu})$ and length of streams $(\mathrm{Lu})$ [3], mean stream length (Lmu) [18], stream length ratio [3], bifurcation ratio (Rb) [19] and mean bifurcation ratio [20] were done using GIS software.

Stream Order: It is the first and basic parameter in the morphometric analysis given by [18] which includes ordering of streams in a hierarchical manner, such as giving $1^{\text {st }}$ order to smallest stream, $2^{\text {nd }}$ order to the stream formed by the combination of two $1^{\text {st }}$ order streams, $3^{\text {rd }}$ order stream is formed where two $2^{\text {nd }}$ order streams merge and accordingly the longest stream or the main channel is given the highest order as shown in Figure 4. Our study area has six watersheds, where the total numbers of streams are 129, 129, 89, 147, 119, and 105 in WS1, WS2, WS3, WS4, WS5, and WS6, respectively. The number of streams order-wise for each watershed has been shown in Table 3. In the study area, $1^{\text {st }}$ order streams make $50.42 \%, 2^{\text {nd }}$ order streams make $26.18 \%, 3^{\text {rd }}$ order streams form $11.14 \%, 4^{\text {th }}$ order contribute $11.84 \%$, and $5^{\text {th }}$ order make $0.42 \%$. WS1, WS2, WS3, and WS5 are identified as $4^{\text {th }}$ order sub-basins, while WS4 is identified under $5^{\text {th }}$ order sub-basin. WS3, WS5, and WS6 are showing sparse vegetation and gentle slope, which can be considered a good potential to get groundwater.

Stream Length $(\mathrm{Lu})$ : Consecutive phases of stream segment development are depicted by Stream length, which is calculated according to Horton Law [3] and [25]. Lower stream length indicates hilly or mountainous regions while long stream lengths are seen in plain or plateau areas. In our area of study, the total stream length of the whole area is $940.19 \mathrm{~km}$ with $141.21,177.61,128.48,197.01$, 151.28 , and $144.6 \mathrm{~km}$ of WS1, WS2, WS3, WS4, WS5, and WS6, respectively, as 
shown in Table 3. Based on Stream Length, groundwater potential is shown by WS1, WS3, and WS6.

Stream Length Ratio (RL): According to Horton's Law [3], the stream length ratio $(\mathrm{Rl})$ is the proportion of the entire stream length of the one order to the concurrent lower order of stream portion [29] [30]. It ranges from 0.80 to 2.15 for the 6 watersheds as shown in Table 4.

Bifurcation Ratio $(\mathrm{Rb})$ and Mean Bifurcation Ratio: The bifurcation ratio expresses the fraction of the number of streams of an assigned order divided by the number of streams in the next higher-order [29]. If the range of $\mathrm{Rb}$ is from ' 3 to 5 'for watersheds then in the belief of [31], drainage pattern is not affected by a geologic structure [28]. In the study area, $\mathrm{Rbm}$ ranges from 1.67 to 2.49 , as shown in Table 4, which can be said that drainage pattern is affected by the geological structures. And the mean bifurcation ratio ranges from 1.66 to 2.44 which indicate the role of geological structures on drainage patterns of the area.

\section{Areal Aspects}

Results obtained from different areal aspects are scrutinized below:

Drainage Density (Dd): Drainage density is the entire length of streams of all orders $(\mathrm{km})$ per drainage area $\left(\mathrm{km}^{2}\right)$ [32] [33]. [18] found that Dd is low, where basin relief is low, while Dd is high where basin relief is high. Low Dd indicates that the area has permeable sub-surface, dense vegetation, and low relief, while high Dd shows impermeable strata, sparse vegetation, and hilly or high relief. According to [3], Dd can be defined as the entire length of channels (Lu) in a drainage basin in proportion to the area (A) of the catchment [28]. Drainage density is divided into five classes with value ranges $\left(\mathrm{km} / \mathrm{km}^{2}\right)$ such as very coarse $(<2)$, coarse $(2-4)$, moderate $(4-6)$, fine $(6-8)$, and very fine $(>8)$ [29] [34] [35]. Drainage density for WS1, WS2, WS3, WS4, WS5 and WS6, are 0.79, $0.90,0.89,0.83,0.82$ and $0.90 \mathrm{~km} / \mathrm{km}^{2}$, respectively, as shown in Table 5. From the analysis of this morphologic parameter, it is seen that WS1 has the highest potential for groundwater followed by WS5 and WS2 has the least potential.

Stream Frequency (Fs): In a basin it may be described as the number of streams per unit area $\left(\mathrm{km}^{2}\right)$ [3] [28]. Higher Fs show a steeper slope, more runoff, more erosion, and less infiltration [36]. The stream frequency of the entire basin is $3.91 \mathrm{~km} / \mathrm{km}^{2}$ and Fs for 6 sub-basins are shown in Table 5, according to which WS3 has the lowest Fs indicating gentle slope and more infiltration, so is considered to be of the highest potential.

Drainage Texture (Rt): It can be described as the complete number of segments in a stream of all orders in a river basin divided by the circumference of the watershed [37]. Its unit is km-1 [32] [33]. The fine texture is shown by an area having sparse vegetation and weak or soft rock formations, whereas coarse texture is shown by densely vegetated and massive or hard rock formations. As shown in Table 5, the area falls under the moderate drainage texture category. Among all 6 sub-watersheds, WS4 is the least groundwater potential, while WS6 has the highest groundwater potential. 
Length of overland flow (Lg): The length of the overland flow $(\mathrm{Lg})$ is about half the reciprocal density of drainage basin [3] [38] [39]. Overland flow length can be explained by the length of the longest drainage path that water takes before it gets concentrated. The range of $\mathrm{Lg}$ for 6 watersheds is from 0.55 to 0.63 . According, to the analysis WS1, falls under the least potential zone and WS2 falls under the highest potential zone for groundwater.

Circularity Ratio $(\mathrm{Rc})$ : The fraction of the basin area $(\mathrm{Au})$ to the area of a circle (Ac) having the same circumference as the basin is called as the circularity ratio [18]. Basin is elongated, having impermeable lithological formations when $\mathrm{Rc}$ is low, whereas basin of circular shape, high to moderate relief when Rc is high. Rc of the whole area ranges between 0.23 to 0.37 , which are shown in Table 5, indicates basins to be of elongated shapes, controlled by high the surface run-off with dense stream network, structurally distorted and lithologically having impermeable formations.

Elongation Ratio $(\mathbf{R e})$ : It is simply defined as the value obtained by dividing the diameter of a circle with the same area as that of the watershed (A) and its maximum length (L). Re is a dimension-less property [29]. When the Re is less than 0.7 , it indicates elongated, 0.7 to 0.8 less elongated, 0.8 to 0.9 oval, and greater than 0.9 circular-shaped basins. The areas are of low relief when Re is close to land areas having high relief or steep slope when Re is equal to 0.6 to 0.8 [18]. According to this WS2 and WS6 falls under the elongated basin shape category; WS1, WS4, and WS5 come in less elongated basin shape category, and WS3 fall in the circular-shaped basin. Also, WS1, WS2, WS4, WS5, and WS6 have high relief or steep ground slope.

Form Factor (Rf): The ratio obtained by dividing the basin area by the square of its basin length, indicates the shape of the basin [29] [39]. Rf indicates elongated basin when its values are smaller and circulate basin when $\mathrm{Rf}$ value is near to 1 . Rf of 6 watersheds ranges from 0.32 to 0.65 as shown in Table 5 indicates that all basins are elongated, with flatted peak flow.

Compactness Constant $(\mathrm{Cc})$ : The correlation of a drainage basin with that of a circular watershed having identical area is defined as Constant of Compactness. The minimum time of concentration before maximum flow occurs is yielded by a circular watershed. The circular behavior of a watershed is indicated by $\mathrm{Cc}=1$. Deviated behavior from circular one is seen of a watershed when Cc $>1$. The Cc for all the drainage basin from WS4 to WS5 is 1.65 to 2.09, was observed as shown in Table 5. The great deviation is seen in WS4 from its circular nature and has the longest time of concentration before peak flow occurs, which is beneficial from a groundwater potential point of view [40].

Shape Index (Sw): It can be defined as the rate of water and sediment accumulated along the length and relief of the sub-watersheds. It values for the watersheds of the study area range from 1.54 for WS3 to 3.09 for WS6 as shown in Table 5. As a result of the analysis, WS3 bears good potential for groundwater and WS6 has the least potential.

Slope: From the slope map as shown in Figure 6, it is clear that the whole 


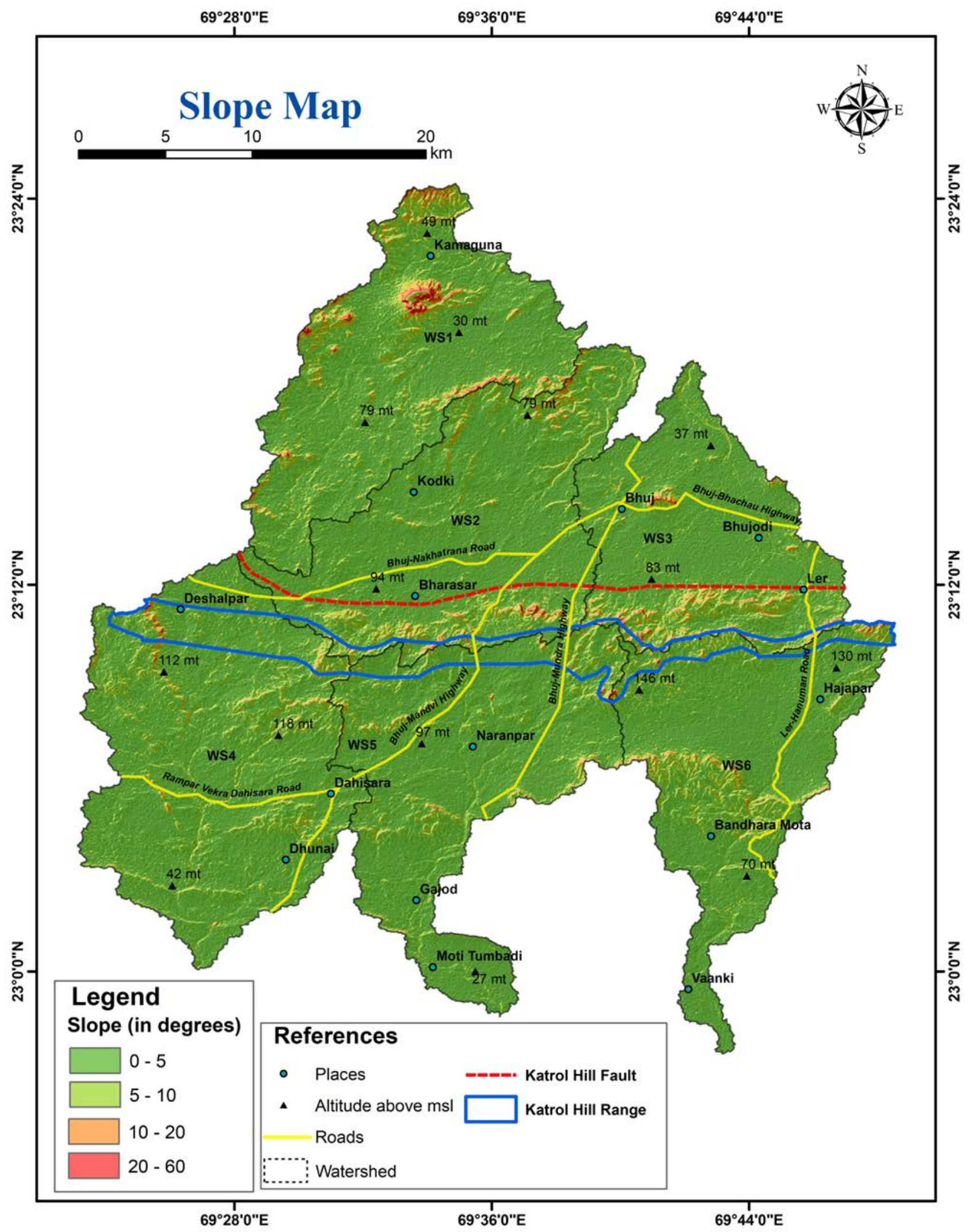

Figure 6. Slope map of the study area. 
area has a general slope of $0^{\circ}-5^{\circ}$, except hilly areas where the slope is varying from $10^{\circ}$ to $60^{\circ}$.

\section{Relief Aspects}

Relief Aspects include Basin relief $(\mathrm{H})$ and relief ratio (Rhl), which are discussed below:

Basin relief $(\mathrm{H})$ : Relief is the highest vertical space between the minimum and the maximum elevation points of a basin, which demarcates the shape and transport of the sediments [41]. The highest elevation of the whole basin is 284 meters and the lowest is 223 meters, so the Basin relief is 61 meters, as shown in Table 5. Analysis shows that WS3 has the lowest relief indicating a good potential zone for groundwater while WS1 and WS6 have the highest relief which is not favorable for groundwater potentials.

Relief Ratio (Rhl): The ratio between total basin relief and its longest dimension parallel to the principal drainage line is called as Relief Ratio. It's a dimensionless number, which indicates the effect of intensity of degradation happening on slopes and shows the steepness of drainage basins [42]. Values of Rhl are high when the basin relief is high, the basin area is small and the basin shape is circular, which can be a mountainous area rather than a plain river basin [24]. In the present study, Rhl ranges from 0.01 to 0.014 for all the 6 watersheds, so WS2 has more potential and WS3 has the least potential for groundwater.

The ranking of the watersheds based on morphometric features is described in Table 5.

Geomorphic characteristics

All the geomorphological parameters are shown in Figure 7.

Moderately dissected hills: This shows the middle stage of geomorphology. WS1 has the highest percentage area for this parameter and WS3 has the least which is about $50.82 \%$ and $26.82 \%$, respectively. As a result, WS3 has the highest groundwater potential.

Pediment: It is a product of erosion and weathering processes, found usually at the bottom of high relief hills or mountains [44]. Higher the relief of the hill or mountain more will be the runoff, erosion, and area of the pediment. In the present study area, the highest percentage area of the pediment is found in WS4 and least in WS3. This means WS3 has low relief and less pediment area, which favors the groundwater recharge and groundwater potential.

Pediplain: They are the results of the erosion or weathering processes, having low relief and mature stage in terms of geomorphology. As shown in Table 6, the percentage area of pediplain is the highest in WS3 and the least in WS1, indicating the potential for groundwater to be in WS3.

Water Bodies: They are naturally occurring features in which water gets stored. More the number of water bodies, more recharge to groundwater can happen and hence groundwater potential zone can be formed. In our study, it is found that WS3 has the least number of water bodies and WS6 has the highest number of them. The ranking of the watersheds based on geomorphic features is described in Table 7. 


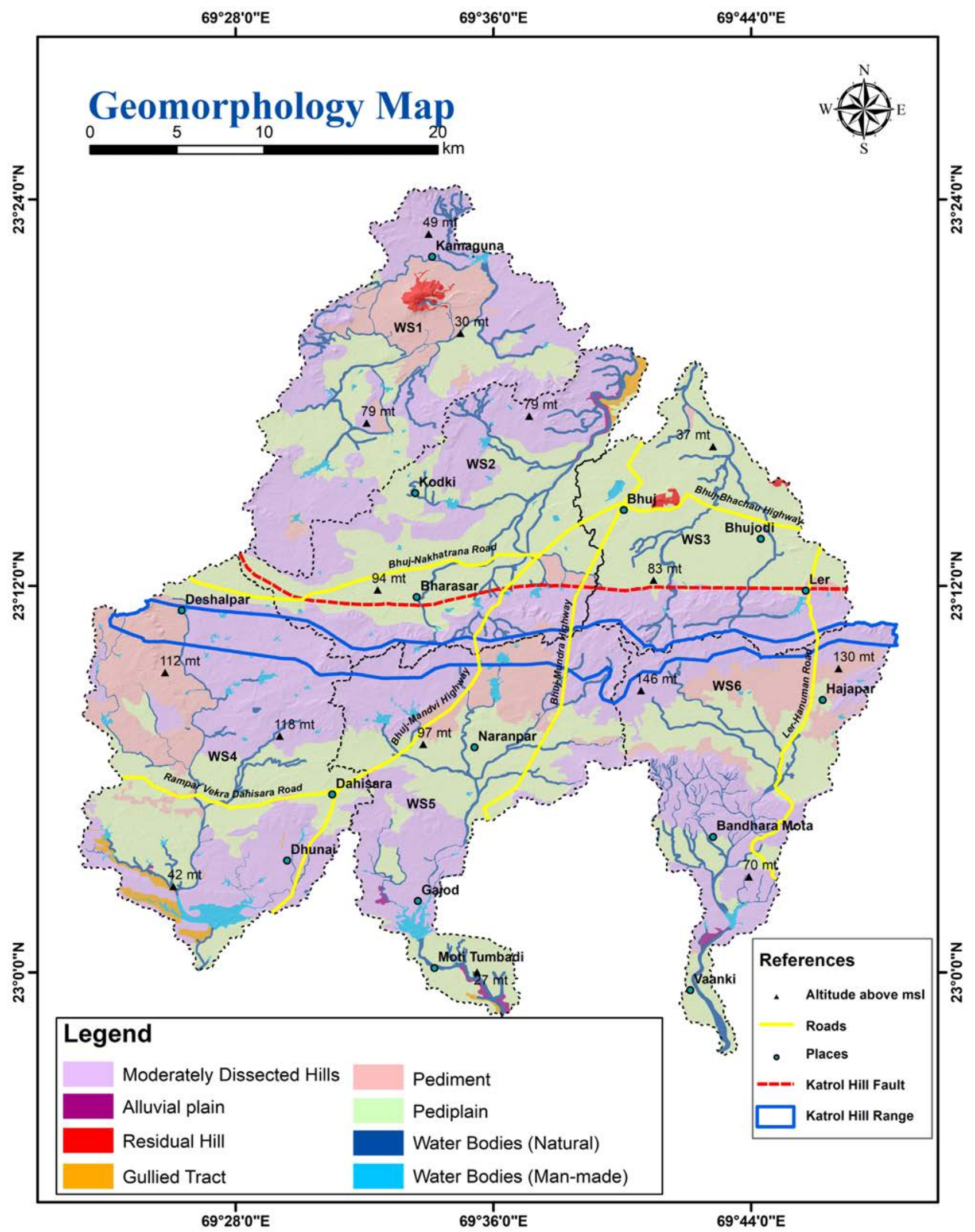

Figure 7. Geomorphological map of the study area showing various geomorphic units in each watershed. 
Table 6. Geomorphology statistics of the watersheds.

\begin{tabular}{|c|c|c|c|c|c|}
\hline \multirow{2}{*}{ Watershed } & \multirow{2}{*}{ Area } & \multicolumn{4}{|c|}{ Geomorphology } \\
\hline & & Dissected Hills & Pediplain & Pediment & Water Bodies \\
\hline \multirow[t]{2}{*}{ WS1 } & $\mathrm{m}^{2}$ & 91.04 & 49.15 & 29.12 & 5.14 \\
\hline & $\%$ & 50.82 & 27.45 & 16.26 & 2.88 \\
\hline \multirow[t]{2}{*}{ WS2 } & $\mathrm{m}^{2}$ & 87.48 & 94.47 & 3.76 & 5.20 \\
\hline & $\%$ & 44.12 & 48.13 & 1.92 & 2.65 \\
\hline \multirow[t]{2}{*}{ WS3 } & $\mathrm{m}^{2}$ & 38.86 & 98.63 & 1.85 & 3.18 \\
\hline & $\%$ & 26.82 & 68.08 & 1.28 & 2.20 \\
\hline \multirow[t]{2}{*}{ WS4 } & $\mathrm{m}^{2}$ & 105.78 & 75.39 & 41.12 & 3.99 \\
\hline & $\%$ & 44.55 & 31.75 & 17.32 & 1.68 \\
\hline \multirow[t]{2}{*}{ WS5 } & $\mathrm{m}^{2}$ & 81.92 & 70.84 & 21.25 & 4.73 \\
\hline & $\%$ & 44.38 & 38.37 & 11.51 & 2.56 \\
\hline \multirow[t]{2}{*}{ WS6 } & $\mathrm{m}^{2}$ & 73.17 & 53.66 & 25.40 & 7.67 \\
\hline & $\%$ & 45.31 & 33.23 & 15.73 & 4.75 \\
\hline
\end{tabular}

Table 7. Geomorphology based watershed prioritization for groundwater potential.

\begin{tabular}{|c|c|c|c|c|c|}
\hline \multirow{2}{*}{ Watershed } & \multicolumn{4}{|c|}{ Land cover categories } & \multirow{2}{*}{ Cp Value } \\
\hline & Dissected Hills & Pediplain & Pediment & Water Bodies & \\
\hline WS1 & 50.82 & 27.45 & 16.26 & 2.88 & \\
\hline Rank & 1 & 1 & 2 & 5 & 2.25 \\
\hline WS2 & 44.12 & 48.13 & 1.92 & 2.65 & \\
\hline Rank & 5 & 5 & 5 & 4 & 4.75 \\
\hline WS3 & 26.82 & 68.08 & 1.28 & 2.20 & \\
\hline Rank & 6 & 6 & 6 & 2 & 5.00 \\
\hline WS4 & 44.55 & 31.75 & 17.32 & 1.68 & \\
\hline Rank & 3 & 2 & 1 & 1 & 1.75 \\
\hline WS5 & 44.38 & 38.37 & 11.51 & 2.56 & \\
\hline Rank & 4 & 4 & 4 & 3 & 3.75 \\
\hline WS6 & 45.31 & 33.23 & 15.73 & 4.75 & \\
\hline Rank & 2 & 3 & 3 & 6 & 3.50 \\
\hline
\end{tabular}

Kachchh is an epitome for the structurally controlled basin, where there are many faults, fractures, joints, and igneous dykes present. As shown in Figure 8, we have divided geological structures into the categories of minor, major and mega structures. If a geological structure (fault, fracture, joint, or dyke) is limited to one watershed only then it is categorized as minor, if a geological structure (fault, fracture, joint, or dyke) is crossing 2 or more watersheds then it 


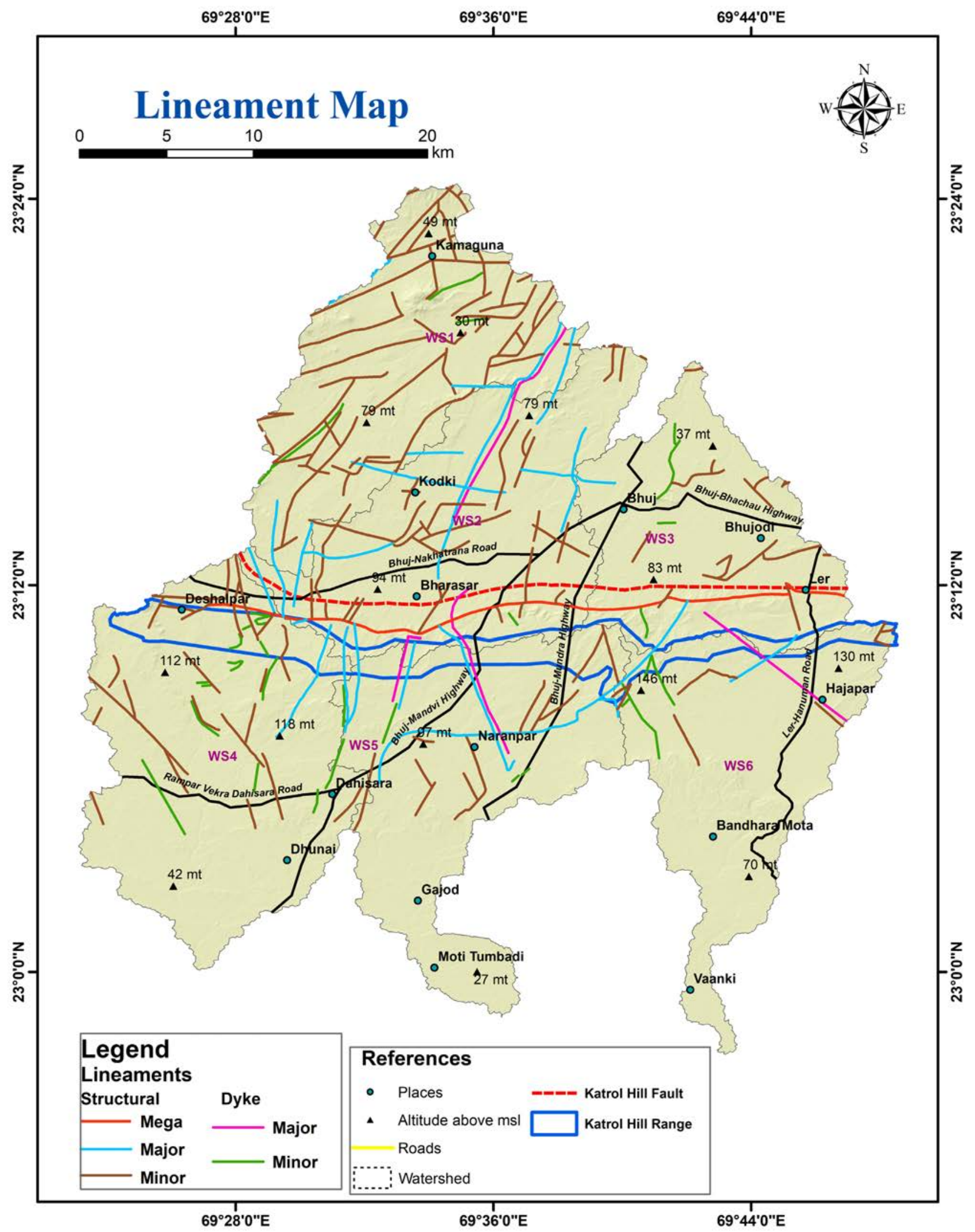

Figure 8. Lineament map of the study area (modified after Biswas [43]). 
is given major category and a geological structure (fault, fracture, joint or dyke) is crossing the whole area or all watersheds, it is given mega category. In the lineament map, it is seen that WS1 and WS4 have several minors to major, WS2 and WS5 have dominantly major geological structures while WS3 and WS6 have the least.

As described above, a common compound value $(\mathrm{Cp})$ for each watershed was derived by using the average of geomorphology and morphometry compound values. The resultant compound values and the respected ranks assigned to each watershed are described in Table 8. The results show that WS3 falls under the excellent category followed by WS2, WS5, and WS6 (Figure 9). The results also reveal that the WS1 falls under the very poor category as this area is mainly covered by dissected hills and valleys (almost 50\%) moreover from the results of morphometric parameters it is evident that this area has the highest relief and highest stream frequency which by themselves indicate the very poor presence of groundwater.

\section{Conclusions}

Morphometric and geomorphic analysis are useful tools to identify groundwater potential zones in the area. It becomes even more convenient when aided by Remote Sensing and Geographical Information System techniques. The present study was aimed to do a morphometric and geomorphic analysis of major river basins across a prominent drainage divide using RS and GIS tools to delimit groundwater potential zones. These various morphometric and geomorphic parameters were analyzed for 6 major river basins.

1) WS1 has low Dd, high length of overland flow, slightly elongated shape with high relief and dissected hills having very less area of pediplains; dominating lithology is Jhuran Formation consisting mainly of shale with sandstone bands. All these make WS1 to be not favoring for groundwater potential.

2) WS2 is an almost circular shaped basin, having low relief with a high percentage of the area having pediplains and lower dissected plains with deltaic sandstones of Cretaceous age as the main lithological unit, but also has a fair

Table 8. Watershed prioritization for groundwater potential based on the combined influence of geomorphology and morphometry.

\begin{tabular}{cccccc}
\hline Watershed & $\begin{array}{c}\text { Cp Value } \\
\text { (Morphometry) }\end{array}$ & $\begin{array}{c}\text { Cp Value } \\
\text { (Geomorphology) }\end{array}$ & $\begin{array}{c}\text { Combined } \\
\text { Cp Value }\end{array}$ & Ranks & $\begin{array}{c}\text { Groundwater } \\
\text { Potential }\end{array}$ \\
\hline WS-1 & 3.42 & 2.25 & 2.83 & 2 & Poor \\
WS-2 & 3.33 & 4.75 & 4.04 & 5 & Good \\
WS-3 & 3.75 & 5.00 & 4.38 & 6 & Excellent \\
WS-4 & 3.58 & 1.75 & 2.67 & 1 & Very Poor \\
WS-5 & 3.92 & 3.75 & 3.83 & 4 & Good \\
WS-6 & 2.92 & 3.50 & 3.21 & 3 & Average \\
\hline
\end{tabular}




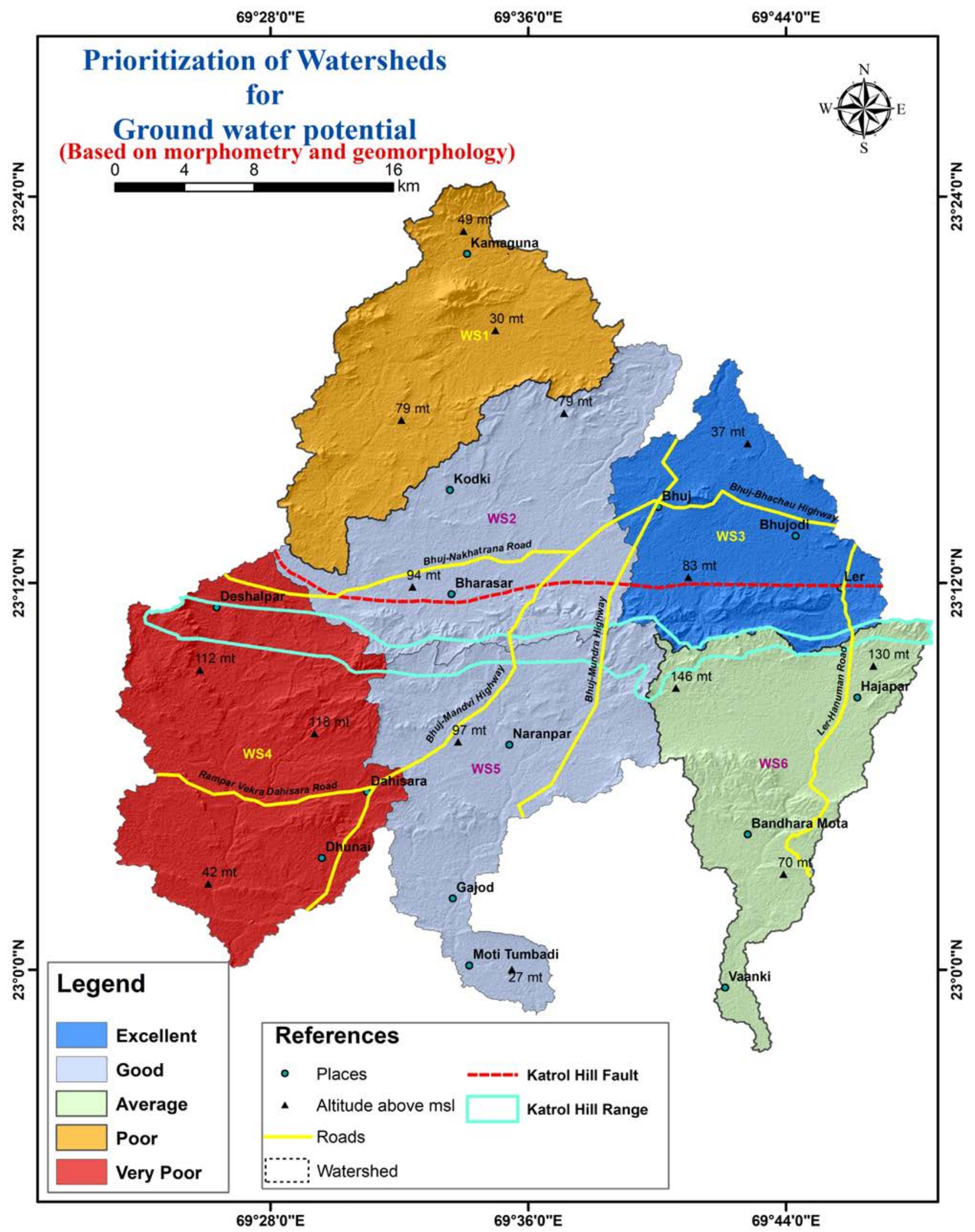

Figure 9. Watershed prioritization ranking map based on the combined impact of morphometry and geomorphology. 
share with dissected hills which results in more area of pediment zone, more drainage density, more stream frequency, making watershed good for groundwater availability.

3) WS3 subsurface mostly consists of deltaic Bhuj sandstone which is the prime aquifers of the Kachchh area. Morphometric parameters such as stream frequency are low, the shape of the basin is near to circular, moderate overland flow length, high Dd with lowest relief among all watersheds, and highest percentage area of pediplain makes it completely suitable as a potential groundwater zone.

4) WS4 has high Dd, low Fs, elongated shape, moderate overland low length and above moderate relief with $24.89 \%$ area having dissected hills, $17.32 \%$ area with pediment, $31.75 \%$ pediplain area, and $19.65 \%$ area having dissected plateau which are above moderate highest, least and moderate, respectively, among all the watersheds. The lithology of WS4 encompasses shales and sandstones, siltstones and basalts of various formations of the Mesozoic age. The deltaic sandstone of the Bhuj Formation is present but covers very less area. All these factors when combined make WS4 a poor basin for groundwater potential.

5) WS5 has low drainage density, moderate stream frequency, slightly elongated basin shape, acceptable Lg, lithology same as that of WS4 and decent percentage area covered by water bodies, pediments, pediplains as well as dissected plateau regions, but basin relief is high, resulting in watershed comparatively good as a groundwater potential zone.

6) WS6 has the same lithology as that of WS4 and WS5, with high Dd, moderate Fs, slightly elongated, low Lg, with the highest area covered by water bodies, dissected plateaus, and least area covered by dissected hills among all the 6 watersheds, pediments and pediplains covering the moderate area. But WS6 has the highest basin relief same as WS1, making it average potential for groundwater.

7) Geological structures such as faults, fractures, and joints are positive structures that promote groundwater flow and recharge but structures like dykes and intrusive are negative which generally, tend to obstruct groundwater flow and recharge. Though WS1 and WS4 have the highest number of positive structures still they form very poor and poor potential respectively, while WS3 has the least structures it forms excellent potential. It can be construed that within an individual basin also, the geological structures are playing a diverse role, which needs to be further studied.

8) These results when verified with static groundwater levels collected from well-inventory for the post-monsoon season showed similarity and confirmation that WS3 forms the best potential for groundwater among all the 6 sub-watersheds.

\section{Acknowledgements}

Ms Hemashri Thacker and Mr Yash Shah are thankful to the ScHeme Of Developing High (SHODH) quality research scheme, the Government of Gujarat for awarding them the research fellowship for their doctoral work. Arid Communi- 
ties and Technologies, Bhuj are acknowledged for technical assistance and financial assistance for the fieldwork. K.S.K.V. Kachchh University, Bhuj is highly acknowledged for its administrative support. This work represents the PhD work of Ms Hemashri Thacker.

\section{Conflicts of Interest}

The authors declare no conflicts of interest regarding the publication of this paper.

\section{References}

[1] Biswas, S.K. (2016) Mesozoic and Tertiary Stratigraphy of Kutch (Kachchh) - A Review. In: Recent Studies on the Geology of Kachchh, Special Publication of Geological Society of India, No. 6, Geological Society of India, Bengaluru, 1-24. https://doi.org/10.17491/cgsi/2016/105405

[2] Clarke, J.I. (1996) Morphometry from Maps: Essay in Geomorphology. Elsevier Publ. Co., New York, 235-274.

[3] Horton, R.E. (1945) Erosional Development of Streams and Their Drainage Basins: Hydrophysical Approach to Quantitative Morphology. Bulletin of Geological Society of America, 56, 275-370. https://doi.org/10.1130/0016-7606(1945)56[275:EDOSAT]2.0.CO;2

[4] Strahler, A.N. (1969) Quantitative Geomorphology of Drainage Basin and Network. In: Chow, V.T., Ed., Handbook of Applied Geomorphology, McGraw Hill, New York, 439-476.

[5] Srivastava, V.K. (1997) Study of Drainage of Jharia Coalfield (Bihar), India, through Remote Sensing Technology. Journal of the Indian Society of Remote Sensing, 25, 41-46. https://doi.org/10.1007/BF02995417

[6] Agarwal, C.S. (1998) Study of Drainage Pattern through Aerial Data in Naugarh Area of Varanasi District, U.P. Journal of the Indian Society of Remote Sensing, 26, 169-175. https://doi.org/10.1007/BF02990795

[7] Magesh, N.S., Jitheshlal, K.V., Chandrasekar, N. and Jini, K.V. (2013) Geographical Information System-Based Morphometric Analysis of Bharathapuzha River Basin, Kerala, India. Applied Water Science, 3, 467-477. https://doi.org/10.1007/s13201-013-0095-0

[8] Sreedevi, P.D., Subrahmanyam, K.E. and Ahmed, S. (2004) The Significance of Morphometric Analysis for Obtaining Groundwater Potential Zones in a Structurally Controlled Terrain. Environmental Geology, 47, 412-420. https://doi.org/10.1007/s00254-004-1166-1

[9] Mishra, S., Kothyari, G.C., Dubey, R.K., Chauhan, G. and Kandregula, R.S. (2021) Morphostructural Approach in Predicting the Geomorphic Attributes of Vigodi Fault, Kachch,, Western India. Arabian Journal of Geosciences, 14, Article No. 594. https://doi.org/10.1007/s12517-021-06818-9

[10] Kothyari, G.C., Kandregula, R.S., Chauhan, G., Desai, B.G., Taloor, A.K., Pathak, V., Swamy, K.V., Mishra, S. and Thakkar, M.G. (2021) Quaternary Landform Development in the Central Segment of Tectonically Active Kachchh Mainland Fault Zone, Western India. Quaternary Science Advances, 3, Article ID: 100018. https://doi.org/10.1016/j.qsa.2020.100018

[11] Bhattacharjee, N. and Mohanty, S.P. (2017) Morphometric Study of the Habo 
Dome, Kachchh, Gujarat, India: Implications on Neotectonic Activity, S.P. AGU Fall Meeting Abstracts.

[12] Bhimani, S.A. (2013) Study on Groundwater Salinization and Formulation of Management Strategies for the Coastal Aquifers of Mundra Region, Kutch District, Gujarat State. Ph.D. Thesis, M.S. University of Baroda, Vadodara.

[13] Tanwar, D.S. and Sharma, L.N. (2017) Delineation of Groundwater Potential Zones Using Remote Sensing and GIS-A Case Study from Pokhran Tehsil, Jaisalmer, Rajasthan. International Journal for Research in Applied Science \& Engineering Technology, 5, 935-943.

[14] Jasmin, I. and Mallikarjuna, P. (2012) Morphometric Analysis of Araniar River Basin Using Remote Sensing and Geographical Information System in the Assessment of Groundwater Potential. Arabian Journal of Geosciences, 6, 3683-3692. https://doi.org/10.1007/s12517-012-0627-1

[15] Altaf, F., Meraj, G. and Romshoo, S.A. (2013) Morphometric Analysis to Infer Hydrological Behaviour of Lidder Watershed, Western Himalaya, India. Geography Journal, 2013, Article ID: 178021. https://doi.org/10.1155/2013/178021

[16] Singh, O. and Singh, J. (2018) Soil Erosion Susceptibility Assessment of the Lower Himachal Himalayan Watershed. Journal Geological Society of India, 92, 157-165. https://doi.org/10.1007/s12594-018-0975-x

[17] Strahler, A.N. (1952) Hypsometric (Area-Altitude) Analysis of Erosional Topography. Bulletin of the Geological Society of America, 63, 1117-1142. https://doi.org/10.1130/0016-7606(1952)63[1117:HAAOET]2.0.CO;2

[18] Strahler, A.N. (1964) Quantitative Geomorphology of Basins and Channel Networks. In: Chow, V.T., Ed., Handbook of Applied Hydrology, McGraw Hill Book Company, New York, 439-476.

[19] Schumm, S.A. (1956) Evolution of Drainage Systems and Slopes in Badlands at Perth Amboy, New Jersey. Bulletin of the Geological Society of America, 67, 597-564. https://doi.org/10.1130/0016-7606(1956)67[597:EODSAS]2.0.CO;2

[20] Strahler, A.N. (1957) Quantitative Analysis of Watershed Geomorphology. Transactions of the American Geophysical Union, 38, 913-920. https://doi.org/10.1029/TR038i006p00913

[21] Horton, R.E. (1932) Drainage Basin Characteristics. Transactions of the American Geophysical Union, 13, 350-361. https://doi.org/10.1029/TR013i001p00350

[22] Miller, V.C. (1953) A Quantitative Geomorphic Study of Drainage Basin Characteristics in the Clinch Mountain Area, Virginia and Tennesse. Project NR 389-042, Technical Report No. 3, University of Geology, Columbia University, New York.

[23] Suresh, M., Sudhakar, S., Tiwari, K.N. and Chowdary, V.M. (2004) Prioritization of Watersheds Using Morphometric Parameters and Assessment of Surface Water Potential Using Remote Sensing. Journal of the Indian Society of Remote Sensing, 32, 249-259. https://doi.org/10.1007/BF03030885

[24] Thomas, J., Joseph, S. and Thrivikramaji, K.P. (2010) Morphometric Aspects of a Small Tropical Mountain River System, the Southern Western Ghats, India. International Journal of Digital Earth, 3, 135-156. https://doi.org/10.1080/17538940903464370

[25] Castillo, V., Diazsegovia, A. and Alonso, S.G. (1988) Quantitative Study of Fluvial Landscapes, Case Study in Madrid, Spain. Landscape and Urban Planning, 16, 201-217. https://doi.org/10.1016/0169-2046(88)90043-6

[26] Sharma, S. and Sarma, J.N. (2013) Drainage Analysis in a Part of the Brahmaputra 
Valley in Sivasagar District, Assam, India, to Detect the Role of Nontectonic Activity. Journal of the Indian Society of Remote Sensing, 41, 895-904. https://doi.org/10.1007/s12524-013-0262-7

[27] Mahala, A. (2019) The Significance of Morphometric Analysis to Understand the Hydrological and Morphological Characteristics in Two Different Morpho-Climatic Settings. Applied Water Science, 10, Article No. 33. https://doi.org/10.1007/s13201-019-1118-2

[28] Sreedevi, P.D., Owais, S., Khan, H.H. and Ahmed, S. (2009) Morphometric Analysis of a Watershed of South India Using SRTM Data and GIS. Journal Geological Society of India, 73, 543-552. https://doi.org/10.1007/s12594-009-0038-4

[29] Sukristiyanti, S., Maria1, R. and Lestiana, H. (2017) Watershed-Based Morphometric Analysis: A Review. Global Colloquium on GeoSciences and Engineering. IOP Conference Series: Earth and Environmental Science, 118, Article ID: 012028. https://doi.org/10.1088/1755-1315/118/1/012028

[30] Makhamreh, Z., Al-Hawary, M. and Odeh, S. (2020) Assessment of Morphometric Characteristics of Wadi Al-Shumar Catchment in Jordan. Open Journal of Geology, 10, 155-170. https://doi.org/10.4236/ojg.2020.102009

[31] Chow, V.T. (1964) Handbook of Applied Hydrology. McGraw Hill Inc., New York.

[32] Rai, P.K., Mishra, V.N. and Mohan, K. (2017) A Study of Morphometric Evaluation of the Son Basin, India Using Geospatial Approach. Remote Sensing Applications. Society and Environment, 7, 9-20. https://doi.org/10.1016/j.rsase.2017.05.001

[33] Vinutha, D.N. and Janardhana, M.R. (2014) Morphometry of the Payaswini Watershed, Coorg District, Karnataka, India, Using Remote Sensing and GIS Techniques. International Journal of Innovative Research in Science, Engineering and Technology (IJIRSET), 3, 516-524.

[34] Chandrashekar, H., Lokesh, K.V., Sameena, M., Roopa, J. and Ranganna, G. (2015) GIS-Based Morphometric Analysis of Two Reservoir Catchments of Arkavati River, Ramanagaram District, Karnataka. Aquatic Procedia, 4, 1345-1353. https://doi.org/10.1016/j.aqpro.2015.02.175

[35] Vittala, S.S., Govindaiah, S. and Gowda, H.H. (2004) Morphometric Analysis of Sub-Watersheds in the Pavagada Area of Tumkur District, South India Using Remote Sensing and GIS Techniques. Journal of the Indian Society of Remote Sensing, 32, 351-362. https://doi.org/10.1007/BF03030860

[36] Puno, G.R. and Puno, R.C.C. (2019) Watershed Conservation Prioritization Using Geomorphometric and Land Use-Land Cover Parameters. Global Journal of Environmental Science and Management, 5, 279-294.

[37] Jain, A.K., Tiwari, A.K. and Sood, A. (2015) Morphometric Analysis of Drainage Basin through GIS: A Case Study of Sukhna Lake Watershed in Lower Shiwalik, India. International Journal of Scientific \& Engineering Research, 6.

[38] Gautam, P.K., Singh, D.S., Kumar, D. and Singh, A.K. (2020) A GIS-Based Approach in Drainage Morphometric Analysis of Sai River Basin, Uttar Pradesh, India. Journal Geological Society of India, 95, 366-376. https://doi.org/10.1007/s12594-020-1445-9

[39] Adhikari, S. (2020) Morphometric Analysis of a Drainage Basin: A Study of Ghatganga River, Bajhang District, Nepal. The Geographic Base, 7, 127-144. https://doi.org/10.3126/tgb.v7i0.34280

[40] Tucker, G.E. and Bras, R.L. (1998) Hill Slope Processes, Drainage Density, and Landscape Morphology. Water Resources Research, 34, 2751-2764. https://doi.org/10.1029/98WR01474 
[41] Hadely, R.F. and Schumm, S.A. (1961) Sediment Sources and Drainage Basin Characteristics in Upper Cheyenne River Basin. USGS Water-Supply Paper, 1531-B, 137-196.

[42] Bhadran, A., Vijesh, V.K., Gopinath, G., Girishbai, D., Jesiya, N.P. and Thrivikramji, K.P. (2018) Morpho-Hypsometric Evolution of the Karuvannur River Basin, a Tropical River in Central Kerala, Southwestern Peninsular India. Arabian Journal of Geosciences, 11, 430. https://doi.org/10.1007/s12517-018-3794-x

[43] Biswas, S.K. (2016) Tectonic Framework, Structure and Tectonic Evolution of Kutch Basin, Western India. Conference GSI. 129-150. https://doi.org/10.17491/cgsi/2016/105417

[44] Tator, B.A. (2008) Pediment Characteristics and Terminology. Annals of the Association of American Geographers, 42, 295-317.

https://doi.org/10.1080/00045605209352147 